\title{
Mitogen-Activated Protein Kinase Kinase Kinase 13
}

National Cancer Institute

\section{Source}

National Cancer Institute. Mitogen-Activated Protein Kinase Kinase Kinase 13. NCI

Thesaurus. Code C102525.

Mitogen-activated protein kinase kinase kinase 13 (966 aa, $108 \mathrm{kDa}$ ) is encoded by the human MAP3K13 gene. This protein is involved in the mediation of serine/threonine phosphorylation. 